\title{
Late Pleistocene cryogenic calcite spherolites from the Malachitdom Cave (NE Rhenish Slate Mountains, Germany): origin, unusual internal structure and stable $\mathrm{C}-\mathrm{O}$ isotope composition.
}

\author{
Detlev Konrad Richter ${ }^{1}$ \& Dana Felicitas Christine Riechelmann ${ }^{1}$
}

\begin{abstract}
:
RichterD.K. and Riechelmann D.F.Ch. 2008. Late Pleistocene cryogenic calcite spherolites from the Malachitdom Cave (NE Rhenish Slate Mountains, Germany): origin, unusual internal structure and stable C-O isotope composition. International Journal of Speleology, 37 (2), 119-129. Bologna (Italy). ISSN 0392-6672.

Cryogenic calcites yielded U-series ages in the range from $15.61 \pm 0.20 \mathrm{ka}$ to $14.48 \pm 0.12 \mathrm{ka}$, which is the youngest age obtained so far for this type of cryogenic cave carbonates in Europe. Most of these particles of the Malachitdom Cave (NE Brilon, Sauerland, North Rhine-Westphalia) are complex spherolites usually smaller than $1 \mathrm{~cm}$. They show $\delta^{13} \mathrm{C}$-values between -1 and $-5 \%$ VPDB and $\delta 180$-values ranging from -7 to $-16 \%$ VPDB, the $\delta^{13} \mathrm{C}$-values increase and the $\delta 180$-values decrease from centre to border. The complex spherolites are interpreted to be formed in slowly freezing pools of residual water on ice, a situation that repeatedly occurred during the change of glacial to interglacial periods in the periglacial areas of Central Europe. After the melting of the caveice, the complex spherolites make up one type of cryogenic calcite particles in the arenitic to ruditic sediment.
\end{abstract}

Keywords: cryogenic cave calcite, Weichselian, C-O isotopes, Malachitdom Cave, Rhenish Slate Mountains, Germany

Received 5 May 2008; Revised 26 May 2008; Accepted 24 June 2008

\section{INTRODUCTION}

Cryogenic cave calcites are quite common in caves in which the air temperatures fall below the freezing point for at least a few months per year. Recently, Žák et al. (2008) and Lacelle (2007) provided a synthesis of various types of cryogenic cave calcite and a comparison of the conditions of freezing (slow or fast) on the morphology and stable $\mathrm{C}-\mathrm{O}$ isotope composition of these secondary cave calcite deposits. It has been suggested by Žák et al. (2008) that fine-grained calcite powders formed during the rapid freezing of water, whereas a more-coarsed grain type formed during the slow freezing of water. Cryogenic cave calcite pearls (spherolites) are a specific type of speleothem currently only discovered in Central European caves (Žák et al., 2004; Richter \& Niggemann, 2005).

According to these studies, the cryogenic cave calcites have a very low stable $O$ isotope composition (-24 to $-9 \%$ o) and based on Th/U dating, formed during the Weichselian glacial period, when Central Europe was under periglacial conditions.

Cryogenic cave calcites have been first described by

1 Institute for Geology, Mineralogy and Geophysics, RuhrUniversity Bochum, Universitätsstr. 150, 44801 Bochum,

Germany. E-mail: Detlev.Richter@rub.de
Viehmann (1960) from Scărişoara Cave in Romania. A description of partial spherolites, similar to the forms discussed here, was made by Tulis and Novotný (1989) from Stratenská Cave in Slovakia. Durakiewicz et al. (1995) found similar forms as Tulis and Novotný (1989) in Chelosiowa Cave in Poland and put them in context with freezing water in glacial times. These forms were also described by Žák et al. (2004) from caves in Poland, Slovakia and Czech Republic and by Richter \& Niggemann (2005) from caves in the Devonian Limestone Complexes of the Rhenish Slate Mountains. According to Žák et al. (2004) and Richter \& Niggemann (2005), the calcite spherolites are precipitating during the very slow freezing of water on ice-bodies in caves when the cave air temperatures fell below freezing, during the Weichselian glacial in Central Europe.

The objective of this study is to determine the origin and age of cave calcite spherolites in the Malachitdom Cave, Rhenish Slate Mountains, Germany. This objective will be reached by examining the internal structure and a possible change in stable $\mathrm{C}-\mathrm{O}$ isotope composition of the spherolitical calcites.

The cupula-spherolites discussed in this study were originally discovered at this location by Schmidt (1992) and the subsequent preliminary investigation 
conducted by Richter \& Niggemann (2005) showed that their stable $\mathrm{C}-\mathrm{O}$ isotope composition was distinct from other types of speleothems in the cave, suggesting a different genetic mechanism.

\section{STUDY AREA}

The Malachitdom Cave system was discovered on 12 June 1987 (Erlemeyer \& Schudelski, 1992) and lies at the northeastern edge of the Limestone Complex of Brilon (Fig. 1) near Bleiwäsche in the quarry of the Sauerländer Hartkalkstein-Industry GmbH. The cave (between $365 \mathrm{~m}$ and $445 \mathrm{~m}$ above sea level) developed in the Middle - Upper Devonian Brilon limestone complex, which spans from the Givetian to the Frasnian (von Kamp, 1998) and reaches a thickness of $1000 \mathrm{~m}$. The Limestone Complex has lagoonal-type facies which are cyclic plate-facies north of a barrier reef (Wizisk, 1995), that marked the position between the basin of the Rhenohercynian in the southeast and the Old-Red-continent in the northwest (Krebs, 1971).

Most karst phenomena (cave development, sinkholes, ponors and so on) observed in the northern part of the Sauerland today developed between the Palaeogene and the Holocene (Meiburg, 1979), though evidence of pre-Tertiary karst formation can be found as well (i.e. the Lower Cretaceous filling of a cave near the small village of Nehden located $11 \mathrm{~km}$ southwest of the study area - Kampmann, 1983). According to Alberts \& Wrede (1992), the Malachitdom Cave, which has four main cavities located at different depths, had multiple development phases starting in the late Tertiary (Fig. 2). The oldest cavity (Kreiselhalle) is located at an elevation of $430 \mathrm{~m}$ and formed during the late Cenozoic. The change between interglacial and glacial periods during the Quaternary caused a drawdown of the water table, and resulted in the development of 3 other cavities at lower elevation (Zentralhalle: 420 m; Halligen: $390 \mathrm{~m}$ and Orkus: $370 \mathrm{~m}$ ). At the lower level (Orkus), cave formation is still active today. This climatic controlled genesis of multiple water table levels over each other (highest level the oldest, lowest level the youngest) does not exclude a deep phreatic initial stadium of the cave genesis. Possibly $\mathrm{CO}_{2}$-rich phases of the hydrothermal solutions, which delivered the ore, could play a role by the cave genesis. These special conditions could explain the formation of such a big cave hall, which is not typical for caves in the Sauerland (Alberts \& Wrede, 1992).

The secondary calcite minerals analyzed in this study were sampled from Halligen and the lower part of the Zentralhalle cavities (Fig. 2). Cave pearls from the Zentralhalle and spikepearls from the Halligen (after Erlemeyer et al., 1992) were sampled from cave pools (Fig. 2). Furthermore spherolites with or without a dish-shaped depression and braid sinter (after Erlemeyer et al., 1992 and Schmidt, 1992) were sampled in the cavity Halligen. There these small speleoforms are found on the cave floor between fallen blocks or on the flat surfaces of these blocks. The sampling has focused mainly on the cupulaspherolites (with depression) and complete spherolites with complex structure (without depression), however other speleothems in the cave (stalagmites, stalactites, cave pearls and others - all from the Zentralhalle) have been sampled as well for the purpose of comparison.

The formation of spherolitical cryogenic calcites is dominated by two types: 1. part spherolites with a dish-shaped concave side and a convex side, which is rich in rhombohedral faces (= cupula-spherolites sensu Schmidt, 1992), 2. complete spherolites which have an external boundary rich in rhombohedral faces, whereas the crystal alignment causes a beakshaped structure on one side of the spherolite (Richter \& Niggemann, 2005).

\section{METHODS}

For documentation of the outer contours of the small speleoforms they have been cleaned in an ultrasonic bath and afterwards been metallized with gold, before

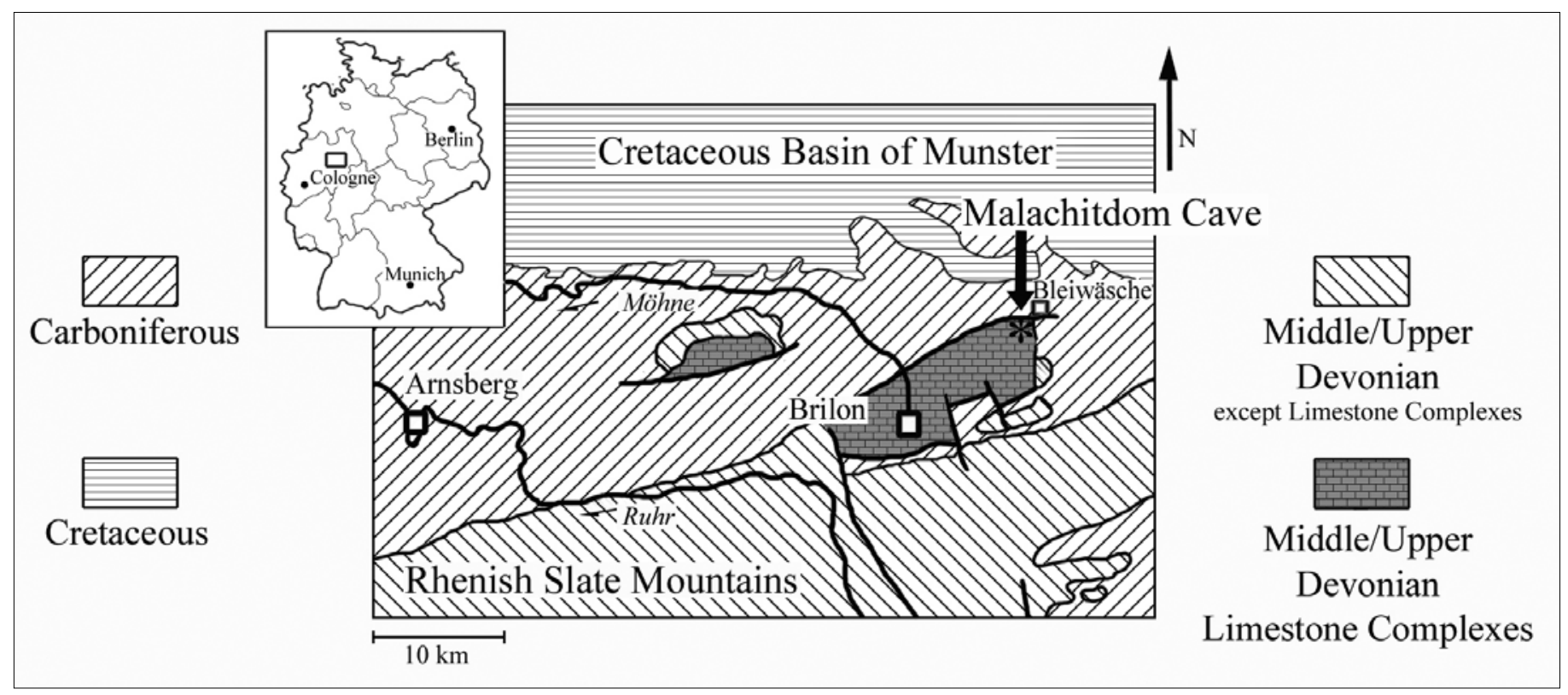

Fig. 1. Geological sketch map of the NE part of the Rhenish Slate Mountains with indication of the position of the Malachitdom Cave in the NE part of the Limestone Complex of Brilon 
$\mathrm{E}$

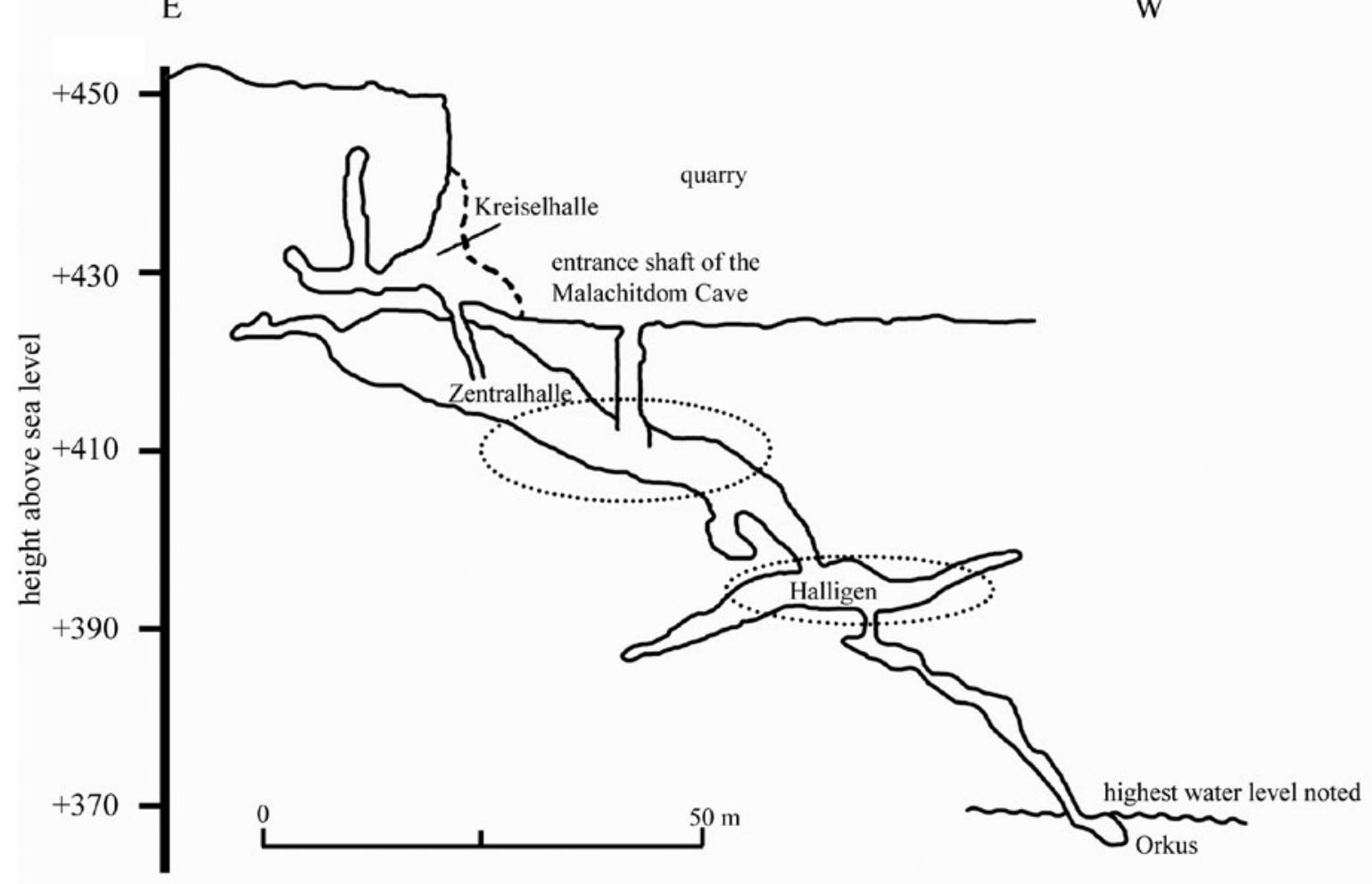

Fig. 2. Longitudinal cut through the Malachitdom Cave (redrawn after Erlemeyer \& Schudelski, 1992) with indication of the sampling areas (see dotted circles)

a high-definition scanning electron microscope (HRFEM) type LEO/Zeiss 1530 Gemini was employed.

The crystallographic orientation of the calcite fibres was determined with a scanning electron microscope using, the "Electron-Back-Scatter-Diffraction" (EBSD) method and the computer program "Channel 5" (Day $\&$ Trimby, 2004), following the methodology described by Neuser \& Richter (2007). Prior to examination the surfaces of the polished thin sections were etched with colloidal silicone (OP-A), followed by a vapour deposition of a thin film of carbon on the sample. The EBSD-analysis provides 3D-information about the micron-nanometer-scale structure of the samples (Day $\&$ Trimby, 2004). To depict the orientation of the crystals scanned over a $1 \mathrm{x} 1$ pointmatrix, the samples were colour-coded, the same colour representing the same orientation and the crystal axes were plotted on a Schmidt diagram.

The mineral compositions of the carbonate phases were obtained by X-ray diffraction (XRD) on a Philips PW 1050/25 x-ray diffractometer equipped with an AMR monochromator applying CuK $\alpha$-radiation (40 kV, $35 \mathrm{~mA})$. The samples were powdered in an agate crucible together with quartz powder, which is used as internal standard, and were measured over the diffraction angle interval of $26-35^{\circ} 2 \theta$ to detect the $\mathrm{d}(104)$-value of the rhombohedral carbonate with respect to their $\mathrm{Ca} / \mathrm{Mg}$-ratio (cp. Füchtbauer $\&$ Richter, 1988), so that all potential rhombohedral carbonates could be detected.

The $\mathrm{C}$ and $\mathrm{O}$ isotopic composition of the cave calcite deposits was determined with a Finnigan MAT Delta
$\mathrm{S}$ isotope ratio mass spectrometer equipped with a GasBench II and calibrated against VPDB (international reference material: IAEA-CO- 1 and IAEA-CO-8). The $1 \sigma$-reproducibility of the measured values of the RUBstandard (internal laboratory standard) is 0.04 for $\delta^{13} \mathrm{C}$ and 0.08 for $\delta^{18} \mathrm{O}$. The sample quantity of $0.5 \mathrm{mg}$ needed for the $\mathrm{C}-\mathrm{O}$ isotope analysis was drilled-out from cut sections of the spherolites with a micromill of the company Merchantek (Dettman \& Lohmann, 1995). The spherolites were cut into two halves and one sample was taken from the centre and two from the outside edge of this cut surface. The $\mathrm{CO}_{2}$ for the measurement is produced in the autosampler by putting phosphoric acid $(\rho=1,913 \mathrm{~g} / \mathrm{ml})$ in the vials and let react this for one hour at $70^{\circ} \mathrm{C}$.

For the ${ }^{87} \mathrm{Sr} /{ }^{86} \mathrm{Sr}$-measurements calcitic powder was dissolved in $2.5 \mathrm{~N}$ suprapur $\mathrm{HCl}$, centrifuged and subsequently the $\mathrm{Sr}$ fraction was separated applying $2.5 \mathrm{~N} \mathrm{HCl}$ to quartz glass columns ( $2.5 \mathrm{ml}$ total volume) and BioRad ion exchange resin (AG-50W-x8, 200-400 mesh). The samples were loaded on Re-single filaments applying $1 \mu \mathrm{l}$ of Ta-activator solution modified after Birck (1986). The ${ }^{87} \mathrm{Sr} /{ }^{86} \mathrm{Sr}$-ratios were measured on a Finnigan MAT 262 solid source mass spectrometer. The data were collected in a peak-jumping (dynamic) mode using three Faraday cups to detect five masses of strontium and rubidium. Sr run comprise 100 to 150 measured ratios; all errors are given as $\pm 2 \sigma$ mean (standard errors). No rubidium correction was applied to the strontium isotopic ratios because the ${ }^{85} \mathrm{Rb}$ signal was below detection limit during the strontium runs in these unspiked samples. For the year 2006 the 
average values for the two SRM's measured routinely are $0.710238 \pm 0.0000382 \sigma(2 \sigma$ mean $=0.000006$ $\mathrm{n}=44$ ) for the NIST NBS 987 , and $0.709160 \pm 0.000029$ $2 \sigma(2 \sigma$ mean $=0.000005 n=35)$ for the USGS EN-1, respectively.

Three samples of the cupula-spherolites, sampled in the cavity Hallingen, were dated with the Th/Umethod at the Heidelberg Academy of Sciences. For one analysis several cupula-spherolites were cut and their surfaces were countersunk with a drill bit. For each sample, between 1 and $2 \mathrm{~g}$ were prepared at the clean laboratory, and their ${ }^{238} \mathrm{U},{ }^{234} \mathrm{U},{ }^{232} \mathrm{Th}$ and ${ }^{230} \mathrm{Th}-$ content analysed by Finnigan Thermal Ionisation Mass Spectrometry (TIMS) MAT 262 RPQ.

\section{RESULTS}

\section{Structure of the spherolites}

The examined spherolites, showing a diameter up to $11 \mathrm{~mm}$, with and without concave side are characterised by a distinctive calcite fibre structure (Fig. 3), the free fibre ends being bordered by vaulted rhombohedral faces. The XRD-recording shows that the calcites have a stoichiometric composition with d(104)values ranging from $3.034 \AA$ to $3.036 \AA$. At first sight the overall combination of the curved rhombohedral faces seems to reflect a calcitic rhombohedron (Fig. 3a), but in detail the curved rhombohedral faces of the single fibres show a stronger concavity (Fig. 3d). This formation was emphasised by EBSD-analyses, as the subcrystals of the single fibres show a specific divergence of the c-axes with respect to their growth direction (Fig. 4). The divergence of the subcrystals in one single fibre is about $40^{\circ}$ and they have a length of $1.4 \mathrm{~mm}$ and an average width of $0.02 \mathrm{~mm}$ (cp. Neuser $\&$ Richter, 2007). This specific orientation results in an undulatory extinction of the single fibres observed with the microscope in the thin sections with crossed nicols.

While the full form calcite fibres have curved rhombohedral faces on all sides (cupulas in the broader sense), the part spherolites (cupulas in the specific sense) have a mesoscopically smooth concave side (Fig. 3e). SEM imaging reveals a rather high micro-porosity of the material (Fig. 3g). For smaller complex spherolites without a concave side the beak- (Fig. 5a) to mace- (Fig. 5b) shaped formation is more distinct in comparison to bigger spherolites (Fig. 3). The smaller complex spherolites are often arranged chain-like (Fig. 5c), so that braid sinter (= Zopfsinter sensu Erlemeyer et al., 1992) develops. It is not uncommon for these braid sinters to have hemispherical recesses of mostly 10 to 100 $\mu \mathrm{m}$ in diameter (Fig. 5c). Ancillary to the spherolitical small forms rhombohedron crystal sinter with bent crystal planes (Fig. 5d) occur, like those that have been described by Richter et al. (2008) as cryogenic calcitic particles of the Heilenbecker Cave in Ennepetal (northern Rhenish Slate Mountains, east of Cologne). Also, these rhombohedron crystals are often stringed chain-like (Fig. 5e) and sometimes show hemispherical recesses (Fig. 5f)

\section{Carbon and oxygen isotopic composition}

The $\delta^{13} \mathrm{C}$ values of the spherolites (mostly of cupula type), braid sinter and rhombohedron crystal sinter fluctuate between -1 and $-5 \%$ VPDB and for $\delta^{18} \mathrm{O}$ between -7 and $-16 \%$ VPDB (Fig. 6). Therefore - regarding the stable isotope chemistry - the composition of these cryogenic cave calcites differs significantly from the composition of "normal" speleothems (stalagmites, stalactites, cave pearls $\delta^{13} \mathrm{C}$ between -6 and $-11 \%$ VPDB and $\delta^{18} \mathrm{O}$ between -4 and $-7 \%$ VPDB) as well as the hostrock (Devonian limestone $-\delta^{13} \mathrm{C}$ between 1 and $3 \%$ VPDB and $\delta^{18} \mathrm{O}$ between -4 and $-6 \%$ VBPD see Fig. 6), as was already indicated in the pilot study by Richter \& Niggemann (2005).

In the course of the present study, the cupulaspherolites were also examined from the inside outwards with respect to their $\mathrm{C}-\mathrm{O}$ isotope composition, the values changing to a lighter $\mathrm{O}$ - and a heavier $\mathrm{C}$-isotope chemistry (Fig. 7). The O-isotope chemistry decreases between 0.15 to $0.94 \%$ from the inside outward of the spherolites and the $\mathrm{C}$-isotope chemistry increases between 0.33 to $1.94 \%$.

\section{${ }^{87} \mathrm{Sr} /{ }^{86} \mathrm{Sr}$-isotopic composition}

The ${ }^{87} \mathrm{Sr} /{ }^{86} \mathrm{Sr}$-isotopic ratios of the two examined cupula-spherolites (0.70950 and 0.70942) differ significantly from the corresponding ratio of a limestone sample (Tab. 1), whose value (0.70827) corresponds to a typical Middle Devonian seawater composition $\left({ }^{87} \mathrm{Sr} /{ }^{86} \mathrm{Sr}\right.$-ratio from ca. 0.7076 to 0.7084 after Veizer et al., 1999). In contrast, the ${ }^{87} \mathrm{Sr} /{ }^{86} \mathrm{Sr}$-isotopic ratios of hydrothermal calcite dykes that lie directly in the area of discovery of the spherolites and are up to 0.5 $\mathrm{m}$ thick, show values between 0.70882 and 0.70981 , this composition being in the range of the examined spherolites (Tab. 1). Another differing ${ }^{87} \mathrm{Sr} /{ }^{86} \mathrm{Sr}$-ratio for caves in Middle Devonian limestone was obtained when analyzing a stalagmite from the Zentralhalle (0.70989), which was located where the cave roof was veined with hydrothermal calcite dykes.

\section{TIMS- Th/U-age determination}

Dating of three cupula-spherolites, from the Halligen, with the Th/U-method resulted in ages between 14.5 and $15.6 \mathrm{ka}$ (Tab. 2). Hence the spherolites formed in the Weichselian glacial, shortly before and during the transition to the Bölling interstadial (MIS 2).

\section{DISCUSSION}

According to Žák et al. (2004, 2008) and Richter \& Niggemann (2005) the different $\mathrm{C}-\mathrm{O}$ isotopic composition of the spherolites, braid sinter and rhombohedron crystal sinter (Fig. 6 and 7) can be ascribed to a calcite formation in the course of the slow freezing of water. The O-isotope chemistry is influenced by the formation of the ice because of a dissociation of the ${ }^{18} \mathrm{O}$ - and ${ }^{16} \mathrm{O}$-isotopes during this process - assuming an isotopic equilibrium.

Because of their stronger chemical bond the ${ }^{18} \mathrm{O}$-isotopes are preferably integrated into the ice during freezing (Clark \& Fritz, 1997). Consequently the ${ }^{16} \mathrm{O}-$ 

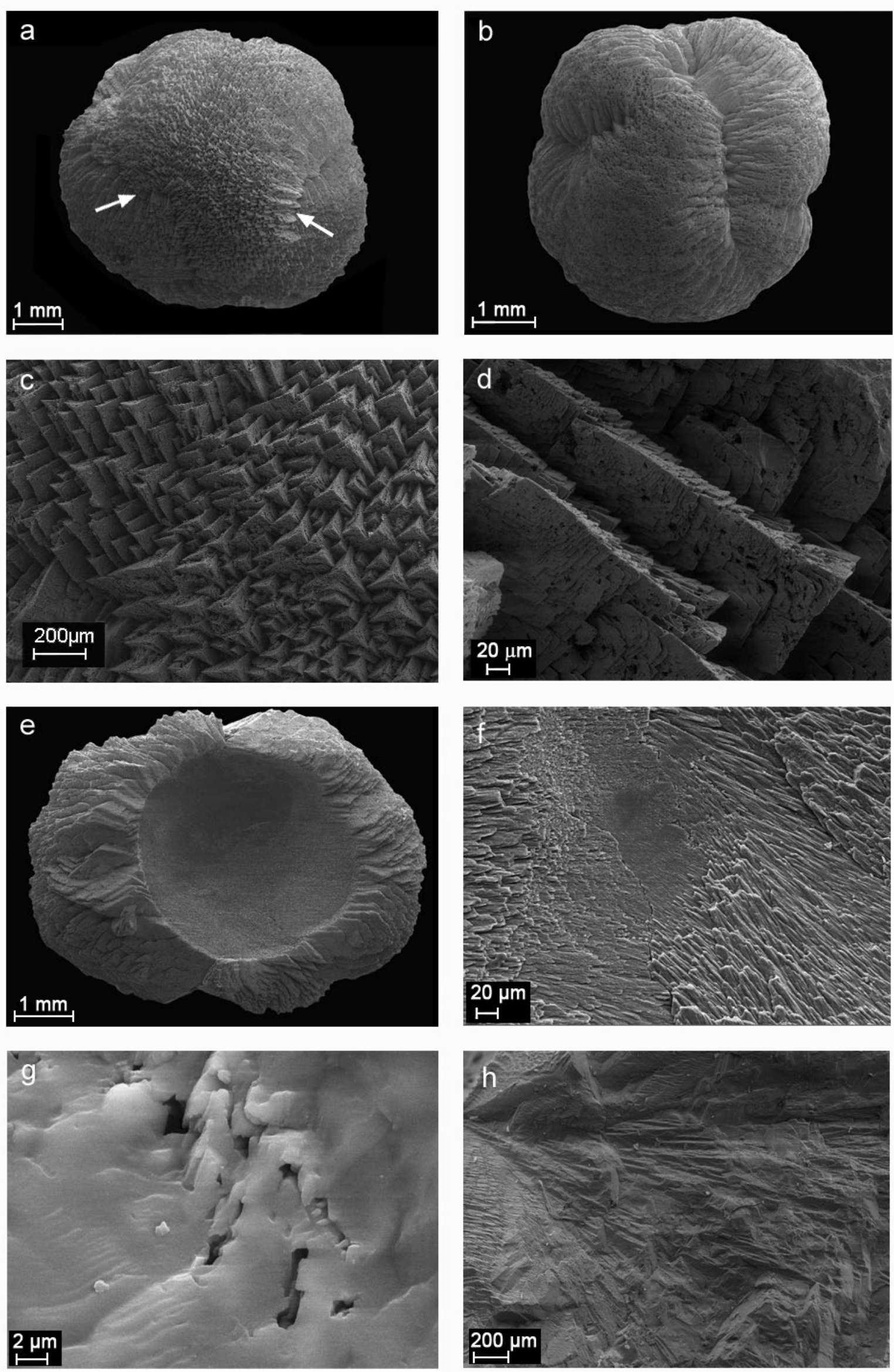

Fig. 3. SEM-pictures of the spherolites. a-convex side, arrows: boundaries between areas of different aligned fibres; b-beak-like form; c-view on the three-fold arranged rhombohedral faces; $d$-arched rhombohedral faces; e-concave side; f-detail of the concave side with fibres; $g$-holes on the surface of breakage; h-alignment of the fibres on the surface of breakage 


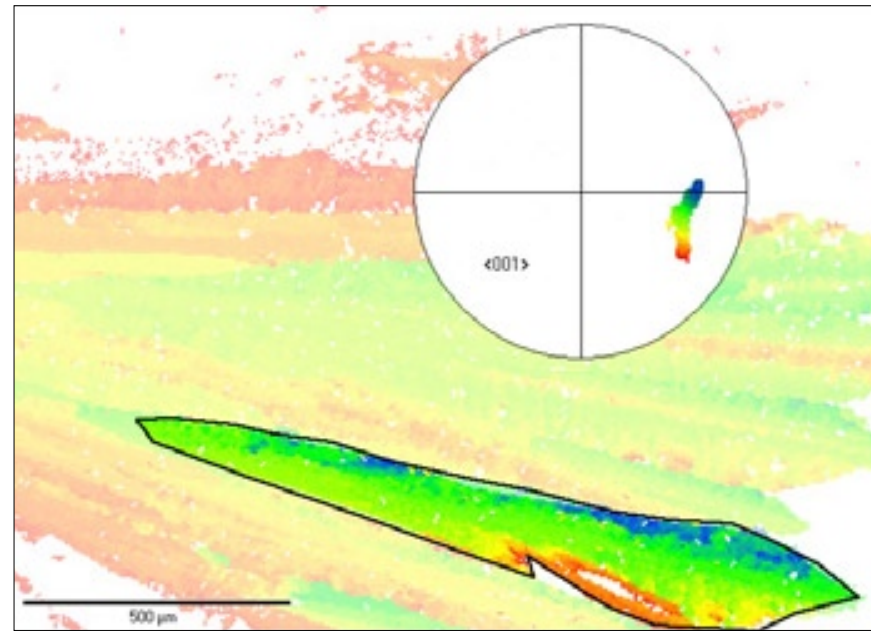

Fig. 4. EBSD orientation maps showing alignment of fibres and the subcrystals within the fibres where similar crystal directions are indicated by same rainbow colours. The pole-plot shows the direction of the c-axes of the framed fibre and points out their fan-shaped orientation. The fan spreads at an angel of about $40^{\circ}$ and has a length of $1.4 \mathrm{~mm}$ and an average width of $0.02 \mathrm{~mm}$.

\begin{tabular}{|c|c|c|c|}
\hline Sample & & ${ }^{87} \mathrm{Sr} /{ }^{86} \mathrm{Sr}$ & $\pm 2 \sigma$ mean \\
\hline Cupula-spherolite & CUP1 & 0.709497 & 0.000007 \\
\hline & CUP2 & 0.709420 & 0.00001 \\
\hline Stalagmite & MATS1 & 0.709890 & 0.000009 \\
\hline Devonian limestone & MK2 & 0.708265 & 0.000007 \\
\hline Hydrothermal calcitic veins & MAL4 & 0.709809 & 0.000007 \\
\hline & MAL7 & 0.708818 & 0.000008 \\
\hline & MAL8 & 0.709583 & 0.000007 \\
\hline
\end{tabular}

Tab. 1. Results of the Sr-isotope analyses

isotopes accumulate in the residual solution, out of which the cryogenic calcites can precipitate slowly upon reaching calcite supersaturation. A slow equilibrium freezing best explains the trend observed in the calcite spherolite: higher $\delta^{18} \mathrm{O}$-values in the centre decreasing to lower values at the outside edge of the spherolites. The relatively high $\delta^{13} \mathrm{C}$-values of the cupula-spherolites, in contrast to the "normal" speleothems, are caused by the degassing of $\mathrm{CO}_{2}$ from the solution from which
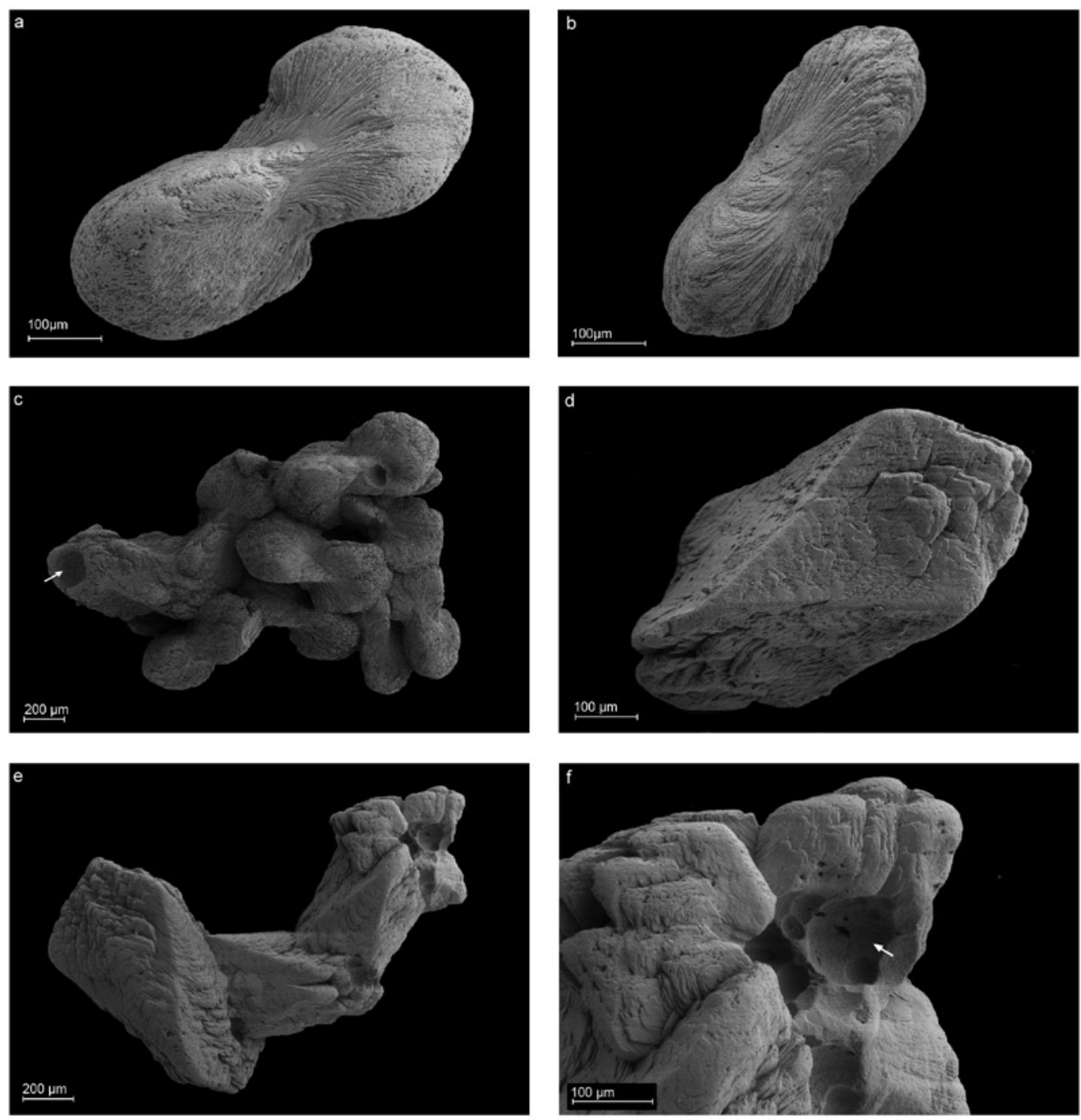

Fig. 5. SEM pictures of cryogenic cave calcites other than cupula-spherolites; partly with eroded surfaces due to redistribution. a-beak-shaped complete spherolite; b-mace-shaped complete spherolite; c-chain-like complete spherolite (= "Zopfsinter" sensu Erlemeyer et al., 1992) with hemispherical recess (see arrow); d-rhombohedron with curved planes; e-chain-like calcite rhombohedrons; f-detail of e with hemispherical recesses (arrow) 


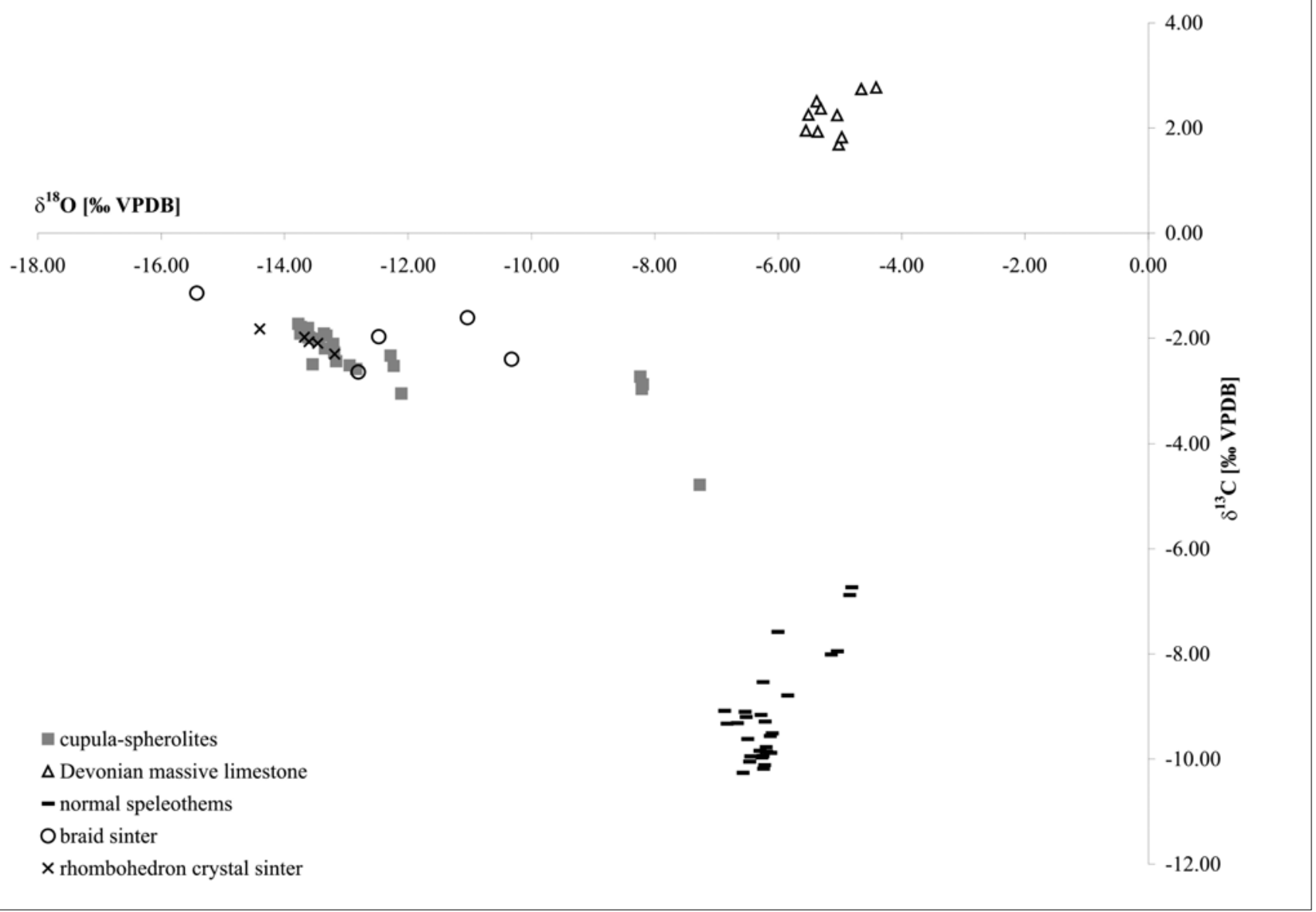

Fig. 6. Comparison of C-O isotope chemistry data of cryogenic cave calcites (cupula-spherolites, braid sinter, rhombohedron crystal sinter), normal speleothems (stalagmites, stalactites, cave pearls) and Devonian limestone

\begin{tabular}{|c|c|c|c|c|c|c|c|c|c|c|c|c|c|}
\hline Lab.No. & Sample & $\delta^{234} U$ * & Error & $238 U$ & Error & ${ }^{232} \mathrm{Th}$ & Error & ${ }^{230} \mathrm{Th}$ & Error & Age (corr.) ** & Error & Age & Error \\
\hline & name & $(\%)$ & & $(\mathrm{ug} / \mathrm{g})$ & & $(\mathrm{ng} / \mathrm{g})$ & & $(\mathrm{pg} / \mathrm{g})$ & & (ka) & (ka) & (ka) & (ka) \\
\hline 4188 & $5 \mathrm{KA} 1$ & 3255.3 & 8.0 & 1.6518 & 0.002 & 5.377 & 0.029 & 14.52 & 0.11 & 14.48 & 0.12 & 14.50 & 0.12 \\
\hline 4275 & $5 \mathrm{KA2}$ & 3242.1 & 8.0 & 1.7179 & 0.002 & 84.19 & 0.75 & 16.30 & 0.20 & 15.61 & 0.20 & 15.93 & 0.20 \\
\hline 4276 & $5 \mathrm{KAI}+\mathrm{II}$ & 3224.1 & 7.3 & 1.3492 & 0.001 & 9.938 & 0.077 & 12.06 & 0.10 & 14.84 & 0.13 & 14.89 & 0.13 \\
\hline
\end{tabular}

* $\delta^{234} U=\left\{\left[\left({ }^{234} U /{ }^{238} U\right) /\left({ }^{234} U / /^{238} U\right)_{e q}\right]-1\right\} * 10^{3}$

$\left({ }^{234} \mathrm{U} /{ }^{238} \mathrm{U}\right)_{\text {eq }}$ is the atomic ratio at secular equilibrium and is equal to $\lambda_{238} / \lambda_{234}=5.489^{*} 10^{-5}$ where $\lambda_{238}$ and $\lambda_{234}$ are the decay constants for ${ }^{238} \mathrm{U}$ and

${ }^{234} \mathrm{U}$, respectively.

$\mathrm{T}$ is the age in years and $\lambda_{230}$ is the decay constant for ${ }^{230} \mathrm{Th} . \lambda_{238}=1.55125^{\star} 10^{-10} \mathrm{y}^{-1} ; \lambda_{234}=2.8263^{*} 10^{-6} \mathrm{y}^{-1} ; \lambda_{230}=9.1577^{\star} 10^{-6} \mathrm{y}^{-1}$ as reported by Cheng et al. (2000). All activity ratios have been corrected for contamination by detrital ${ }^{238} \mathrm{U},{ }^{234} \mathrm{U}$ and ${ }^{230} \mathrm{Th}$, assuming a silicate source with a ${ }^{232} \mathrm{Th} /{ }^{238} \mathrm{U}$ ratio of 3.8 , and with ${ }^{230} \mathrm{Th},{ }^{234} \mathrm{U}$ and ${ }^{238} \mathrm{U}$ in secular equilibrium. The age uncertainty includes the analytical contribution from the parameters $\delta^{234} \mathrm{U}$ and $\left.{ }^{230} \mathrm{Th} /{ }^{238} \mathrm{U}\right)$ but not the uncertainty in the detrital correction. The detrital correction is not significant within the analytical uncertainty for all samples.

Tab.2 . Results of the U/Th-age determination of the cupula-spherolites

the ice crystallises. Sensu Clark \& Fritz (1997), the lighter ${ }^{12} \mathrm{C}$-isotopes prefer the gas phase and the ${ }^{13} \mathrm{C}$ isotopes accumulate in the solution. The calcite crystals precipitate from this residual liquid at supersaturation and have a heavier C-isotopic composition than "normal" speleothems (Žák et al., 2004, cp. Fig. 6). The Rayleighfractionation causes a progressive accumulation of ${ }^{13} \mathrm{C}$ isotopes in the residual liquid and hence the trend in the spherolites from lower values in the centre to higher values at the outside edge.

The formation of the cryogenic calcites of the Malachitdom Cave described in this study, which precipitated from a solution during the slow freezing of water, can be illustrated with a cartoon series (Fig. 8):

Phase a:

Short periods of warmer climate allow for percolation to occur in the upper part of a former permafrost profile and builds up an ice body in the cave. 


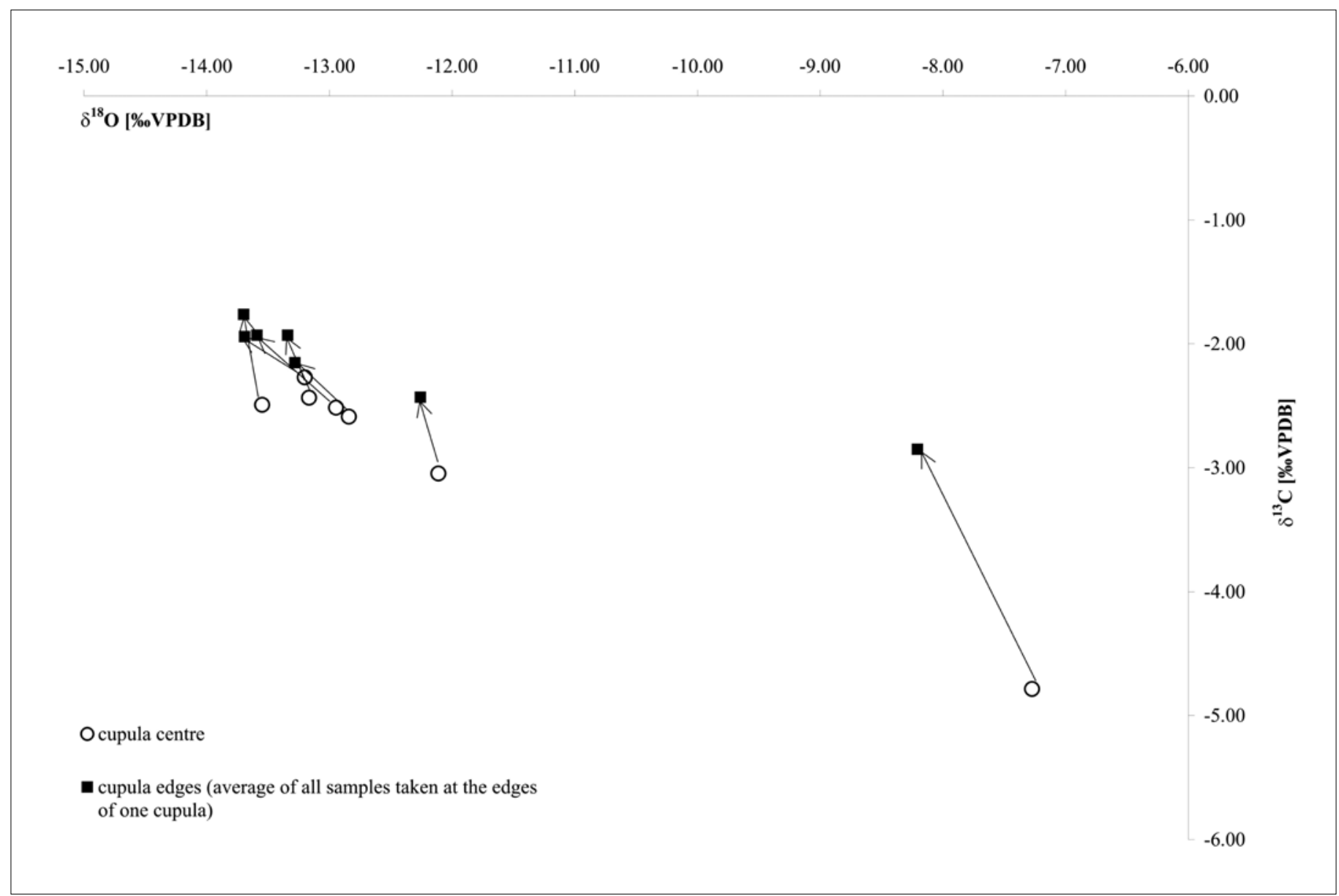

Fig. 7. C-O isotopic composition of the cupula-spherolites showing a trend from the inside to the outside (arrows)

Phase b:

During minor warmer periods (fluctuations nearly around $0^{\circ} \mathrm{C}$ ) water stays liquid and forms small pools on the surface of the ice, in which the cryogenic calcites form very slowly because of consecutively decreasing temperatures (sensu Žák et al., 2004). At the same time the blocks in contact with the cave wall are cemented by calcite.

Phase c:

The cryogenic calcites are enclosed, when the water freezes slowly. Mild climate fluctuations (summertime, but also warming for longer periods) result in the formation of several generations. In this situation cryogenic calcites with different formation could develop as described by Richter et al. (2008) from the Heilenbecker Cave in Ennepetal (northern Rhenish Slate Mountains - east of Cologne).

Phase $\mathrm{d}$ :

The post-glacial warming causes the ice to melt and the cryogenic calcite sediments accumulate on the cave floor. Sometimes different cryogenic calcite types and generations were blended into one accumulation. The blocks attached to the cave wall remain as so called ice attachment ("Eishaftung" sensu Pielsticker, 2000).

The ${ }^{87} \mathrm{Sr} /{ }^{86} \mathrm{Sr}$-ratio of the cryogenic spherolites being high comparing to that of limestone can be explained by solution effects occurring at the numerous calcitic dykes with higher Sr-fraction in the material overlying the area where the cryogenic cave calcites were found in the Malachitdom Cave, because normally the Sr-isotope chemistry of speleothems in Middle Devonian limestones of the Rhenish Slate Mountains corresponds to that of the hostrock (cp. Dietzel et al., 2001). This analysis was important because an example from Morocco shows that not necessarily the speleothems have to reflect the $\mathrm{Sr}$-isotopic composition of the hostrock. There the ${ }^{87} \mathrm{Sr} /{ }^{86} \mathrm{Sr}$-isotopic ratio was influenced by siliciclastic dune material above the cave and not by the Upper Cretaceous limestone (Buhl et al., 2007).

At large the cryogenic calcites of the Malachitdom Cave are the youngest known in Central European caves so far (Fig. 9) with ages from 14.5-15.6 ka. In the course of other examinations the knowledge of these special small speleoforms will certainly be broadened. On the one hand the exact formation of the different shaped cryogenic calcites is not clear and could be clarified with the observation of modern-time ice caves with similar temperature conditions. On the other hand formation of cryogenic calcites during older ice-ages has to be assumed. The systematic disorder in the calcite lattice has to be seen three-dimensional, so that an equal pattern is not possible on the whole spherelike periphery of the spherolites. So, on the outside several "seams" marking switches of pattern can be seen (Fig. 3a), resulting in a beak-shaped form of the cupulas (Fig. 3b).

According to the XRD-recording, the concavity of the rhombohedral faces of the fibres has to be caused by 

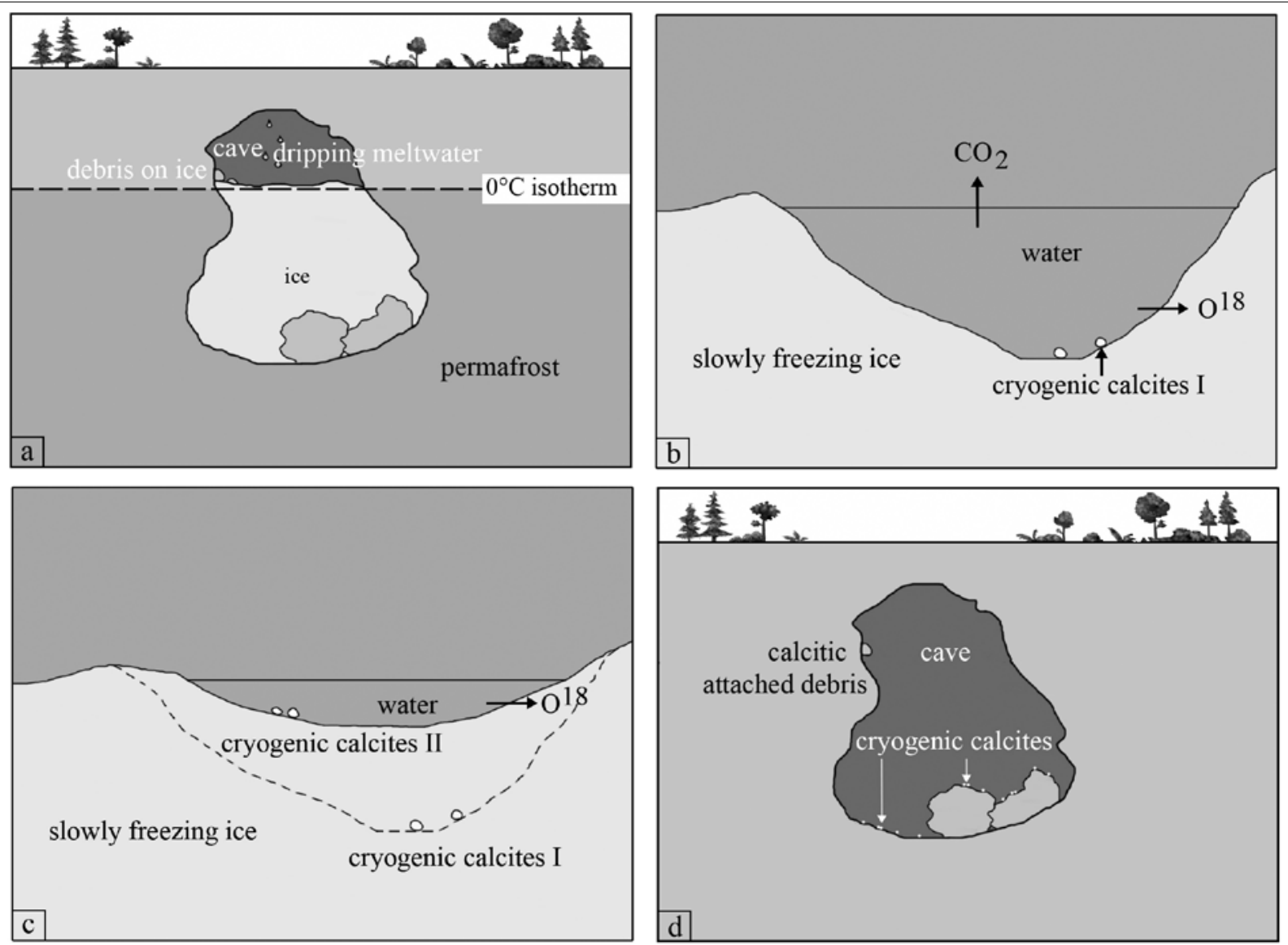

Fig. 8. Cartoon showing the formation of the complete spherolites - $a$ and d show a profile of a cave, $b$ and $c$ mark detail on the ice a-because of a slow climatic warming water infiltrates into a cave which still lies in the zone of permafrost; b-initially small amounts of water remain liquid on the surface of the ice; in these pools the cryogenic calcites form very slowly; c-when the freezing progresses slowly the calcites are enclosed in the ice; climatic fluctuations can result in the formation of several generations of cryogenic calcites; d-during the postglacial warming the ice melts and the calcite sediments accumulate onto the cave floor

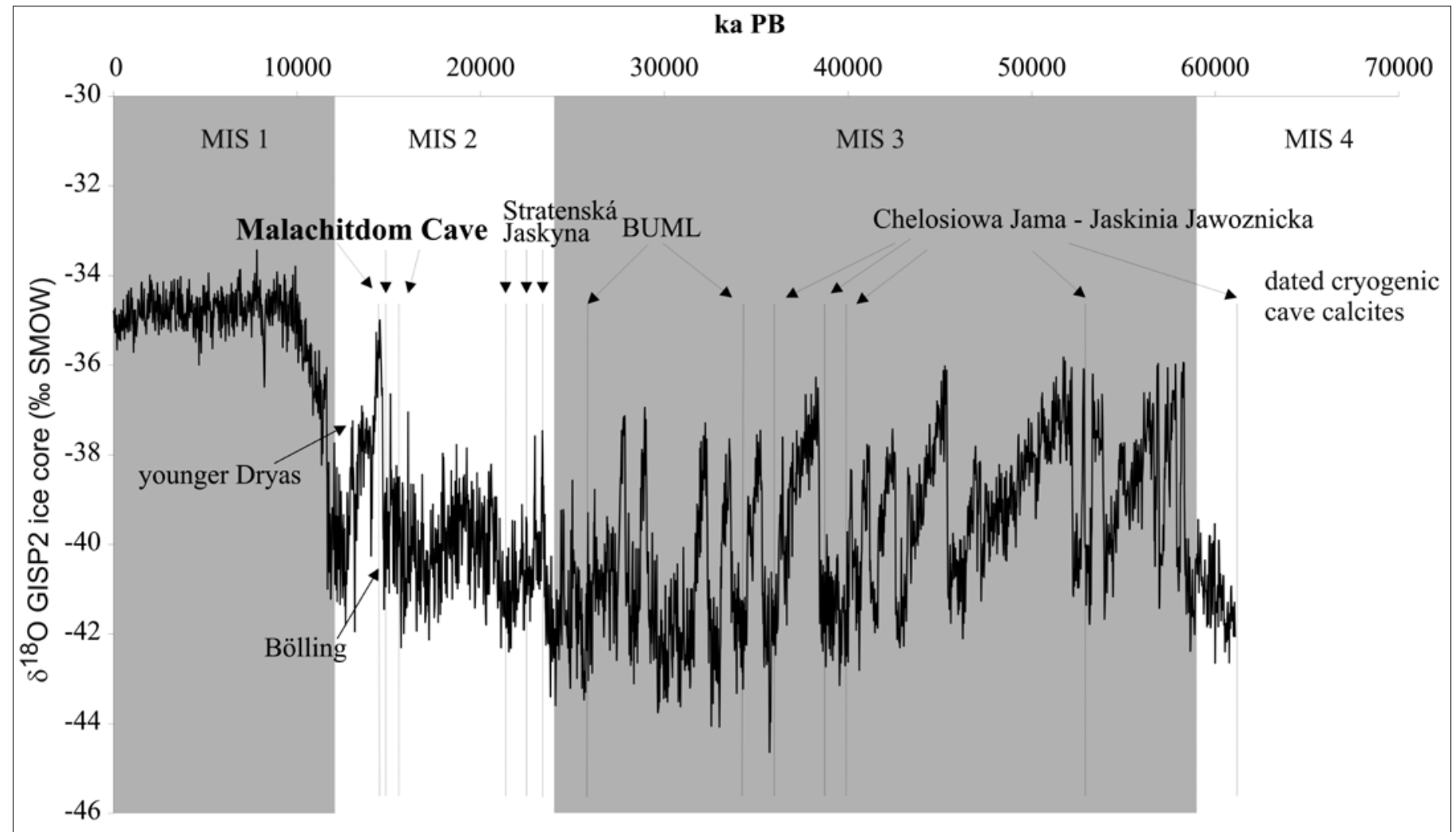

Fig. 9. Dated samples from the Malachitdom Cave and the analyses by Žák et al. (2004) plotted against the $\delta^{18} \mathrm{O}$ GISP ice core record (Martinson et al., 1987) 
systematic lattice defects without influence of foreign cations like Mg. Even if the cryogenic speleoforms consist of calcite nowadays, an initial formation of some metastable carbonates and later recrystalisation to calcite cannot be excluded. The EBSD-analysis evidences that the complex spherolitic structure is constituted solely of subparallel oriented fibres with a divergence in the single fibres.

The concave surface marks a growth limit for the calcite fibres against a material that is no longer present and from which the part spherolites originally started to form. In addition the genesis of this concave side of the cupulas s. str. remains unparalleled in current observations. As the formation of the spherolites began at different places and diverged to the outside, it cannot be the result of solution effects of complete spherolites, as Schmidt (1992) firstly supposed in connection with so-called condensed-water-corrosion. The smooth surface ranging from being curved to hemispheric indicates that the respective spherolite formed on a material which cannot be reconstructed today. One possibility is the formation of frost pearls in the overcooled and humid cave air during phase a (Fig. 8), which froze on the cave ice-body and represented hemispheric uprisings in the subsequent pool stadium. Pigments on such uprisings could have served as a germ for the genesis of the cupulaspherolites. Another theory is the formation of the smooth concave side due to gasbubbles, which can be found under the rim of ice encroaching from the edges of the pool and on the sides of it. Similar recesses are observed in floating rafts in cave pools, which are created by small gasbubbles (Taylor \& Chafetz, 2004). The concave forms, which were found on the braid sinters and on the rhombohedron crystal sinter, can also be interpreted as overgrown small gas bubbles.

\section{CONCLUSION}

Polymict composed calcareous sediments between and on blocks in the Malachitdom Cave near Brilon (northeastern Rhenish Slate Mountains, Germany) contained preferential spherolitic speleothems composed of calcite particles, whose formation refers to ice-age conditions near the $0^{\circ} \mathrm{C}$ isotherm in temporary existing pools on the cave ice. The methodical multifaceted physicals (SEM, XRD, EBSD, $\mathrm{C}-\mathrm{O}-$ and $\mathrm{Sr}$-isotope chemistry, TIMS-Th/U-age determination) focused on the up to $11 \mathrm{~mm}$ big complex composed spherolites because their calcite structure is developed uniformly.

The examined spherolites can be classified into two subtypes: a. part spherolites with a concave side, b. complete spherolites with a beak-shaped structure. The geochemical physics have been concentrated on subtype a (cupula-spherolite).

The almost stoichiometric composed calcite spherolites are built of fibres with little bent rhombohedron surfaces at the periphery. The individual fibres that build up the spherolite show an undulatory extinction, which indicates a divergence of the c-axes (see fig. 4).

The $\delta^{13} \mathrm{C}$-values vary between -1 and $-5 \%$ VPDB and the $\delta^{18} \mathrm{O}$-values between -7 and $-16 \%$ VPDB, this discerns the cryogenic cave calcites clearly from the "normal" speleothems $\left(\delta^{13} \mathrm{C}-6\right.$ to $-11 \%$ o VPDB and $\delta^{18} \mathrm{O}-4$ to $-7 \%$ VPDB) as well as from the Middle Devonian limestone $\left(\delta^{13} \mathrm{C} 1\right.$ to $3 \%$ VPDB and $\delta^{18} \mathrm{O}-4$ to $-6 \%$ VPDB). Inside the spherolites the $\delta^{18} \mathrm{O}$-values get increasingly negative and the $\delta^{13} \mathrm{C}$-values increasingly positive with the growth of the fibres.

The ${ }^{87} \mathrm{Sr} /{ }^{86} \mathrm{Sr}$-isotopic ratios of the spherolites range between 0.70942 and 0.70950 and differ clearly from the values of the Middle Devonian limestone and therefore the former seawater. They correspond to the values of hydrothermal calcite dykes in the hostrock, so that the hydrothermal products may be responsible for the more radiogenic values of the spherolites.

TIMS- Th/U-age determination $(14.5$ to 15.6 ka) proves a genesis of the spherolites during the Weichselian glacial before and during the transition to the Bölling interstadial (MIS 2).

Due to the $\mathrm{C}-\mathrm{O}$ isotopic composition the cryogenic cave calcites are formed in slowly freezing pools of residual water near the $0^{\circ} \mathrm{C}$-isotherm sensu Žák et al. (2004). Thereby the TIMS- Th/U-data prove a period during the transition to the Bölling interstadial, so that several generations are probable.

After the deglaciation of the cave ice the different cryogenic calcite types as well as generations have admixed to a polymict sediment on the cave floor.

\section{ACKNOWLEDGEMENTS}

We thank the Sauerländer Hartkalkstein-Industry $\mathrm{GmbH}$ (branch location Bleiwäsche) for granting access to their property. For providing the knowledge of someone familiar with the place while attending the drawing of the samples in the Malachitdom Cave we are much indebted to A. Schudelski (Rösenbeck). Technical support we owe to the staff of the Institute for Geology, Mineralogy and Geophysics of the Ruhr-University Bochum - M. Born and A. Schulz (thin section fabrication), R. D. Neuser (SEM and EBSD), B. Gehnen and U. Schulte (C-O isotope chemistry), D. Buhl (Sr isotope chemistry), A. Schäffer (graphic editing). The TIMS Th/U-age determinations were made by the kind and generous D. Scholz at the research centre for radiometry of the Heidelberg Academy of Science. We express our thanks to reviewers D. Lacelle, B.P. Onac and K. Žák for constructive comments.

\section{REFERENCES}

Alberts B. \& Wrede V., 1992 - Der Malachitdom bei Wünnenberg-Bleiwäsche - Erforschung und Bedeutung. In: Geologisches Landesamt Nordrhein-Westfalen (Ed.) - Der Malachitdom. Ein Beispiel interdisziplinärer Höhlenforschung im Sauerland. Krefeld: 9-18.

Birck J.L., 1986 - Precision K-Rb-Sr isotopic analysis; application to $\mathrm{Rb}-\mathrm{Sr}$ chronology. Chemical Geology, 56 (1-2): 73-83. 
Buhl D., Immenhauser A., Smeulders G., Kabiri L. \& Richter D.K., 2007 - Time series $\delta^{26} \mathrm{Mg}$ analysis in speleothem calcite: Kinetic versus equilibrium fractionation, comparison with other proxies and implications for palaeoclimate research. Chemical Geology, 244: 715-729.

Cheng H., Adkins J., Edwards R.L. \& Boyle E.A., $2000-U$-Th dating of deep-sea corals. Geochimica et Cosmochimica Acta, 64 (14): 2401-2416.

Clark I. \& Fritz P., 1997 - Environmental Isotopes in Hydrogeology. Lewis Publisher, New York, 328 p.

Day A. \& Trimby P., 2004 - Channel 5. HKLTechnology, Hobro, 339 p.

Dettman D. \& Lohmann K.C., 1995 - Microsampling carbonates for stable Isotope and minor element analysis: physical separation of samples on a 20 micrometer scale. Journal of Sedimentary Petrology, A65: 566-569.

Dietzel M., Wiegand B. \& Rosendahl W., $2001-{ }^{18} \mathrm{O} /{ }^{16} \mathrm{O}$, ${ }^{13} \mathrm{C} /{ }^{12} \mathrm{C},{ }^{87} \mathrm{Sr} /{ }^{86} \mathrm{Sr}$ and ${ }^{230} \mathrm{U} /{ }^{234} \mathrm{Th}$ composition of a speleothem from a cave in Western Germany. European Journal of Mineralogy, Beihefte, 3/1: 40.

Durakiewicz T., Halas S., Migaszewski M., Urban J., 1995 - Origin of "calcite groats" in the Chelosiowa Cave near Kielce (Holy Cross Mts.) inferred from petrographic and isotopic investigations. Geol. Quarter., 39 (1): 75-94.

Erlemeyer M. \& Schudelski A., 1992 - Der Malachitdom und die anderen Höhlen im Steinbruch Düstertal. In: Geologisches Landesamt Nordrhein-Westfalen (Ed.) - Der Malachitdom. Ein Beispiel interdisziplinärer Höhlenforschung im Sauerland. Krefeld: 39-68.

Erlemeyer M., Hasenmayer B. \& Schudelski A., 1992 - Das Höhlensystem Kreiselhalle-Malachitdom - ein bemerkenswerter Aufschluss für Höhlenminerale. In: Geologisches Landesamt Nordrhein-Westfalen (Ed.) - Der Malachitdom. Ein Beispiel interdisziplinärer Höhlenforschung im Sauerland. Krefeld: 69-89.

Füchtbauer H. \& Richter D.K., 1988 - Karbonatgesteine. In: Füchtbauer H. (Ed.) - Sedimente und Sedimentgesteine. Fourth edition. Stuttgart: E. Schweizerbart'sche Verlagsbuchhandlung: 233-434.

Kampmann H., 1983 - Mikrofossilien, Hölzer, Zapfen und Pflanzenreste aus der unterkretazischen Sauriergrube bei Brilon-Nehden. Beitrag zur Deutung des Vegetationsbildes zur Zeit der Kreidesaurier in Westfalen. Geol. Paläont. Westf., 1: 1-146.

Krebs W., 1971 - Devonian Reef Limestones in the Eastern Rhenish Schiefergebirge. In: Sedimentology of parts of Central Europe - Guidebook to Excursions held during the VIII International Sedimentological Congress 1971 in Heidelberg, Germany. Frankfurt am Main: Verlag Waldemar Kramer: 45-83.

Lacelle D., 2007 - Environmental setting (micro) morphologies and stable $\mathrm{C}-\mathrm{O}$ - isotope composition of cold climate carbonate precipitation - A review and evaluation of their potential as paleoclimatic proxies. Quaternary Science Reviews, 26 (11-12): 1670-1689.
Martinson D.G., Pisias N.G., Hays J.D., Imbrie J., Moor T.C. Jr. \& Shackleton N.J., 1987 - Age Dating and the Orbital Theory of the Ice Ages: Development of a HighResolution 0 to 300,000 - Year Chronostratigraphy. Quaternary Research, 27: 1-29.

Meiburg P., 1979 - Kreide-Transgression und Paläokarst im Gebiet der Warsteiner Karbonatplattform (Westfalen). Aspekte der Kreide Europas, IUGS, Series A, 6: 363384.

Neuser R.D. \& Richter D.K., 2007 - Non-marine radiaxial fibrous calcite; examples of speleothems proved by electron backscatter diffraction. Sedimentary Geology, 194: 149-154.

Pielsticker K.-H., 2000 - Höhlen und Permafrost Thermophysikalische Prozesse von Höhlenvereisungen während des Quartärs. Bochumer geol. u. geotechn. Arb., 55: 187-196.

Richter D.K. \& Niggemann S., 2005 - Kryogene Calcite in Höhlen des Rheinischen Schiefergebirges. Mitteilungen Verb. dt. Höhlen- u. Karstforsch., 51 (4): 129-132.

Richter D.K., Neuser R.D. \& Voigt S., 2008 - Kryogene Calcitpartikel aus der Heilenbecker Höhle in Ennepetal (NE`Bergisches Land/Nordrhein-Westfalen). Die Höhle, (in press).

Schmidt F.X., 1992 - Mineralogische Besonderheiten aus dem Höhlensystem Kreiselhalle-Malachitdom. In: Geologisches Landesamt Nordrhein-Westfalen (Ed.) - Der Malachitdom. Ein Beispiel interdisziplinärer Höhlenforschung im Sauerland. Krefeld: 91-104.

Taylor P.M. \& Chafetz H.S., 2004 - Floating rafts of calcite crystals in cave pools, central Texas, U.S.A.: Crystal habit $v s$. saturation state. Journal of Sedimentary Research, 74 (3): 328-341.

Tulis J. \& Novotný L., 1989 - System of Stratenská Cave. Osveta Publishers, Martin, 464 p. (in Slovak with English summary).

Veizer J. Ala D., Azmy K., Bruckschen P., Buhl D., Bruhn F., Carden G.A.F., Diener A., Ebneth S., Godderis Y., Jasper T., Korte C., Pawellek F., Podlaha O. \& Strauss H., $1999-{ }^{87} \mathrm{Sr} /{ }^{86} \mathrm{Sr}, \delta^{13} \mathrm{C}$ and $\delta^{18} \mathrm{O}$ evolution of Phanerozoic seawater. Chemical Geology, 161: 5988.

Viehmann I., 1960 - Un nouveau processus de genèse des perles de caverne. Československý Kras, 12 (1959): 177-185 (in Czech with French abstract).

von Kamp H., 1998 - Erläuterungen C4714 Arnsberg. Geologische Karte von Nordrhein-Westfalen 1:100.000, Krefeld, 79 p.

Wizisk U., 1995 - Mikrofazielle Entwicklungsgeschichte des devonischen Briloner Riffkomplexes (Sauerland). Diss. Ruhr-Universität Bochum, Bochum: 130 p.

Žák K., Onac B.P. \& Perşoiu A., 2008 - Cryogenic carbonates in cave environments: A review. Quaternary International, (in press).

Žák K., Urban J., Cílek V. \& Hercman H., 2004 Cryogenic cave calcite from several Central European caves: age, carbon and oxygen isotopes and a genetic model. Chemical Geology, 206: 119-136. 